\title{
PEMBELAJARAN MATEMATIKA BERBASIS SOFTWARE DI SMAN 6 TANGERANG SELATAN
}

\author{
Dewi Purnama Sari' ${ }^{1)}$, Isnurani ${ }^{2)}$, R. Aditama ${ }^{3)}$, Usep Rahmat ${ }^{4)}$, NurulLita Sari ${ }^{\text {5) }}$ \\ 1,2,3,4,5 Program Studi Matematika, Fakultas MIPA, Universitas Pamulang
}

\begin{abstract}
Abstrak
Tujuan pengabdian kepada masyarakat yaitu untuk meningkatkan pengetahuan dan keterampilan siswa dalam pembelajaran matematika di sekolah SMAN 6 kota Tangerang Selatan. Siswa mendapatkan pengetahuan dan keterampilan mengenai media pembelajaran berbasis software SPSS dalam melakukan perhitungan secara cepat dan tepat mengenai analisis deskriptif data. Sasaran dalam pengabdian yaitu peserta didik di sekolah SMAN 6 kota Tangerang Selatan. Permasalahan diselesaikan melalui 3 tahapan yaitu persiapan awal, pelaksanaan kegiatan dan evaluasi kegiatan. Persiapan dilakukan melalui survey awal pendahuluan untuk mengetahui kondisi mitra di lapangan terkait permasalahan yang dialami peserta didik saat belajar matematika melalui daring. Tahap pelaksanaan kegiatan dilakukan melalui proses pengajaran secara online menggunakan ceramah dalam menyampaikan informasi kepada peserta didik, dilanjutkan latihan pengolahan data dengan software SPSS. Evaluasi masing-masing tahapan dengan mengumpulkan dan menyimpulkan data serta analisis data tersebut. Hasil kegiatan melalui pengamatan selama proses kegiatan dan dilanjutkan dengan wawancara terhadap 3 siswa mengenai proses pelatihan software SPSS dalam statistik desriptif pada materi statistika diperoleh : (1) Siswa sangat antusias mengikuti proses pelatihan menggunakan media pembelajaran software SPSS, karena mereka mendapat pengetahuan baru terkait penggunaan software SPSS dalam belajar matematika. (2) Meningkatkan pengatahuan dan pemahaman siswa SMAN 6 Tangerang Selatan untuk membantu dalam menyelesaikan permasalahan terkait pelajaran statistika. (3) Meningkatkan keterampilan siswa SMAN 6 Tangerang Selatan dalam penggunaan media pembelajaran berbasis ICT menggunakan software SPSS.
\end{abstract}

Kata kunci: media pembelajaran, software SPSS, statistika matematika

\begin{abstract}
The purpose of community service is to increase the knowledge and skills of students in learning mathematics at the school of SMAN 6, South Tangerang city. Students gain knowledge and skills about learning media based on SPSS software in performing calculations quickly and accurately regarding descriptive data analysis. The target of this community service is students at SMAN 6, South Tangerang city. Basic problems in 3 stages, namely initial preparation, implementation and evaluation activities. Preparation is done through preliminary preliminary surveys to see the condition of partners in the field related to problems that students learn when learning mathematics through courage. The implementation stage which is carried out online uses lectures in conveying information to students, training data processing with SPSS software. Evaluate each stage by collecting and concluding the data and analyzing the data. The results of observations during the interview process with 3 students regarding the SPSS software training process in descriptive
\end{abstract}


statistics on statistical material were obtained: (1) Students were very enthusiastic about participating in the training process using SPSS software learning media, because they got new knowledge related to the use of SPSS software in learning mathematics. (2) Improve students' knowledge and understanding of SMAN 6 South Tangerang to help solve problems related to lesson statistics. (3) Improve the skills of students of SMAN 6 Tangerang Selatan in the use of ICT-based learning media using SPSS software.

Keywords: learning media, SPSS software, mathematical statistics

Correspondence author: Dewi Purnama Sari, dewidepsya@yahoo.com, Tangerang, Indonesia

\section{PENDAHULUAN}

"Matematika ada semenjak manusia ada (Nabi Adam AS)", pernyataan tersebut membuat pemikiran kita menjadi terbuka lebar. Panjangnya perjalan matematika sampai saat ini sehingga banyak hal yang bisa kita pelajari. Artinya bagi pecinta matematika menjadi hal menarik untuk memahami sejarah perkembangan ilmu matematika. Dengan memahami sejarah perkembangan ilmu matematika akan memperdalam rasa cinta untuk terus mengembangkan keilmuan dalam matematika.

Saat ini dunia sedang mengalami kasus virus corona atau covid-19 yang melanda awal tahun 2019 di Indonesia. Virus tersebut menular dari Wuhan, hamper menyebar keseluruh dunia. Hal ini sangat berdampak kepada perekonomian maupun pendidikan. Pemerintah Indonesia melalui menteri pendidikan mengeluarkan Surat Edaran No.2 Tahun 2020 tentang pencegahan dan penanggulangan. Pembelajaran daring di pilih pemerintah melalui Kemendikbud dalam tata cara proses pembelajaran di masa pandemi Covid-19. Semua pihak dari pemerintah, penyelenggara pendidikan, pendidik, siswa maupun orang tua harus saling bahu membahu untuk kelancaran proses belajar daring. Meskipun pembelajaran jarak jauh hanya berlaku untuk daerah yang termasuk zona merah, kuning dan orange. Sementara untuk daerah zona hijau dapat melakukan pembelajaran secara langsung melalui tatap muka asal memperhatikan aturan protokol kesehatan yang sudah ditetapkan pemerintah. Meski kegiatan belajar mengajar dilakukan di rumah, sebagai guru wajib tetap melaksanakan dan memantau proses belajar mengajar. Bahkan pemantauan online jauh lebih ekstra dibandingkan secara offline. Karena banyak kendala yang dilalui seperti masalah koneksi dan kendalan kemampuan mengoperasikan media online.

Pembelajaran online dengan jarak jauh memiliki keuntungan maupun kerugian yang dapat mempengaruhi proses maupun hasil belajar peserta didik di sekolah. Pembelajaran daring akan menjadi efektif apabila memiliki sarananya maupun prasarana yang mendukung diantaranya HP, computer atau lamptop dan jaringan internet. Ada beberapa keuntungan jika pembelajaran secara online seperti guru akan meningkatkan pengetahuan dengan mencari informasi terkait penggunaan media untuk menunjang pembelajaran daring, aktif untuk memperbaharui macam-macam aplikasi dalam belajar online, supaya siswa tetap tertarik dan semangat dalam belajar. Dari sisi lain, siswa harus mengoptimalkan waktu dalam belajar, serta siswa harus lebih giat untuk menyelesaikan tugas yang telah diberikan guru. Dengan siswa belajar dari rumah sehingga waktu lebih 
banyak dan memungkian siswa untuk menyelesaikan tugas dari proses pembelajaran yang diberikan sekolah. Melalui pembelajaran online siswa dituntut dan termotivasi dalam mencari sumber-sumber bahan ajar dari internet guna menambah informasi pelajaran dengan harapan mengurangi kebiasaan maen game online. Keuntungan lainya bagi para orang tua siswa yaitu dapat memantau dalam proses belajar anaknya sehingga peran orang tua saat pembelajaran daring sangat menentukan keberhasilan dalam proses pembelajaran. Selain itu, komunikasi orang tua dengan guru sekolah akan lebih intens, meskipun melalu media sosial.

Tidak semua mata pelajaran mudah untuk dilakukan pembelajaran jarak jauh, salah satunya pelajaran matematika. Karena belajar matematika membutuhkan penjelasan langsung dan cukup waktu untuk mempelajarinya. Ini menjadi kelemahan tersendiri bagi guru dan siswa. Sehingga tidak sedikit siswa mencari jawaban melalui jaringan internet, ini mengakibatkan siswa hanya memindahkan jawaban tanpa memahami apa yang dia kerjakan. Lebih parahnya lagi karena kesulitan dalam mengerjakan tugas matematika, sehingga sebagian siswa kehilangan motivasi dalam belajar. Tentunya ini menjadi dampak buruk bagi siswa tersebut dalam proses belajar. Melalui pembelajaran, siswa diharapkan menjadi pribadi yang berkualitas baik dalam bidang ilmu pengetahuan, teknologi dan akhlak. Salah satu luaran yang bisa diamati dari proses pembelajaran adalah hasil belajar. Hasil belajar siswa merupakan hal penting dalam kegiatan pendidikan. Ciri hasil belajar bisa dinyatakan dengan skala nilai sebagai prestasi untuk mengukur aspek kognitif (Tambunan, 2018). Untuk itu prestasi dapat diartikan sebagai kemampuan atau penguasaan siswa terhadap suatu materi yang diajarkan.

Penggunaan media pembelajaran berbasis ICT khusunya dalam belajar matematika sudah dilakukan cupuk lama. Salah satunya software SPSS yang digunakan untuk membantu dalam mempelajari statistika. Software SPSS adalah program komputer yang digunakan dalam menganalisi perhitungan statistika. Dengan bantuan software SPSS dapat dengan cepat mengetahui hasil dari analisi statitika. Mendapatkan hasil belajar yaitu dapat melalui penilaian. Menurut Wilian (2011) hanya melalui penilaian kita bisa menemukan dan mengetahui apakah rangkaian aktivitas pembelajaran tertentu telah menghasilkan yang diinginkan (Van der Kleij et al., 2015). Dengan demikian sebuah penilaian merupakan sarana informasi untuk mengetahui hasil dari proses pembelajaran.

Ketika proses pembelajaran jarak jauh siswa sering menggunakan handphone maaupun komputer. Banyak aplikasi maupun software yang bisa membatu siswa dalam belajar matematika., sehingga pembelajaran berbasis software akan membuat siswa lebih semangat dalam belajar matematika khusunya. Sudah banyak penelitian yang dilakukan terkait penggunaan software dalam pembelajaran diantaranya, penelitian oleh Sakinah Zubair dengan menggunakan software Macromedia Flash 8 (Zubair, 2015). Penelitian Hamidah dan Indah Resti mengenai pembelajaran interaktif menggunakan Software Lectora Inspire (Resti, 2018). Dari penelitian tersebut diperoleh hasil bahwa penggunaan software meningkatkan interaktif dan motivasi siswa dalam belajar. Skaalvik \& Rankin (1995) menemukan bahwa motivasi berkaitan erat dengan prestasi akademik (Singh et al., 2002). Proses belajar akan dilakukan dengan baik jika seorang siswa sudah termotivasi baik secara pribadi maupun pengaruh dari luar. Sehingga motivasi belajar menjadi hal yang penting diperhatikan oleh pendidik maupun orang tua. Motivasi dan pembelajaran mungkin memiliki hubungan timbal balik, karena motivasi mempengaruhi siswa dalam menyelesaikan tugas akademiknya.

Berdasarkan latar belakang tersebut, Program Pengabdian Masyarakat (PKM) Universitas Pamulang (UNPAM) terpanggil untuk ikut serta dalam membatu mengatasi 
kesulitan siswa dalam belajar matematika. Tujuan umum dalam melakukan proses pengabdian kepada masyarakat (PKM) ini untuk membantu peserta didik dalam mengatasi menghadapi persoalan-persoalan selama pembelajaran daring khusunya pelajaran Statistika kelas 12. Secara khusus kegiatan dilakukan dengan tujuan adalah: (1) Memperkenalkan pembelajaran matematika berbasis software SPSS kepada siswa. (2) Membantu peserta didik dalam memecahkan perhitungan statistika menggunakan software SPSS. (3) Membantu peserta didik untuk meningkatkan dasar eksakta matematika sebagai prasyarat dalam mempelajari matematika. (4) Membantu untuk menumbuhkan rasa percaya diri pada peserta didik dalam memahami dan belajar matematika. (5) Membantu peserta didik dalam meningkatkan hasil belajar matematika di sekolah.

\section{METODE PELAKSANAAN}

Sasaran program pengabdian masyarakat yang akan dituju adalah peserta didik SMAN 6 Tangerang Selatan. Kegiatan berlokasi di SMAN 6 Tangerang Selatan melalui pembelajaran daring via webex. Permasalahan diselesaikan melalui 3 tahapan yaitu persiapan awal, pelaksanaan kegiatan dan evaluasi kegiatan. Persiapan dilakukan melalui survey awal pendahuluan untuk mengetahui kondisi mitra di lapangan terkait permasalahan yang dialami peserta didik saat belajar matematika melalui daring. Tahap pelaksanaan kegiatan dilakukan melalui proses pengajaran secara online menggunakan ceramah dalam menyampaikan informasi kepada peserta didik, dilanjutkan latihan pengolahan data dengan software SPSS. Evaluasi masing-masing tahapan dengan mengumpulkan dan menyimpulkan data serta analisis data tersebut. Hasil kegiatan melalui pengamatan selama proses kegiatan dan dilanjutkan dengan wawancara terhadap 3 siswa mengenai proses pelatihan software SPSS dalam statistik desriptif pada materi statistika.

\section{HASIL DAN PEMBAHASAN}

Tahapan persiapan untuk mengetahui permasalahan mitra dilakukan melalui survey pendahuluan mengenai kesulitan belajar peserta didik selama pembelajar online di masa pandemi covid-19. Tim PKM berkoordinasi dan melakukan wawancara terhadap guru matematika SMAN 6 Tangerang Selatan, untuk membicarakan media dalam pembelajaran dengan menggunakan software SPSS dalam analisis deskripsi data di dalam materi statistika. Hasil koordinasi dan wawancara didapatkan bahwa media pembelajaran berbasis software SPSS memang belum diperkenalkan kepada peserta didik, sehingga guru sangat merekomendasikan dan mendukung tim PKM dalam memperkenalkan pepmebalajran berbasis software SPSS bagi peserta didik khusunya di SMAN 6 kota Tangerang Selatan.

Kegiatan pelaksanaan pengabdian dilakukan melalui daring via webex yang diikuti 30 peserta didik kelas 12 . Narasumber dan pendamping dalam proses pelaksanaan adalah dosen Universitas Pamulang yang tergabung dalam tim PKM di SMAN 6 Tangerang Selatan. Kegiatan tersebut dilakukan dengan penyampaian materi dengan metode 
ceramah serta diskusi dan dilanjutkan dengan pelatihan atau workshop. Bahan materi yang disampaiakan saat pelatihan disajikan tabel 1 .

Tabel 1 Bahan Materi Pelatihan

\begin{tabular}{cl}
\hline No & Materi \\
\hline 1 & Pengertian software SPSS untuk perhitungan statistik \\
\hline 2 & Langkah-langkah menggunakan software SPSS \\
\hline 3 & Contoh penggunaan software SPSS untuk analisis deskriptif frekuensi dan diagram \\
\hline 4 & Workshop penggunaan software SPSS \\
\hline
\end{tabular}

Materi pertama peserta didik diberikan informasi terkait media dalam pembelajaran yang bisa digunakan. Dengan perkembangan teknologi yang sangat pesat tentunya mudah kita mencari pengetahuan atau media-media yang bisa digunakan untuk membantu proses pembelajaran terlebih saat ini pembelajaran daring, sehingga setiap hari peserta didik pasti menggunakan handphone atau komputer. Dalam pengolahan data statistika yang sedang dipelajari peserta didik kelas 12 tentang, distribusi frekuensi, menghitung ratarata, media dan modus bisa menggunakan bantuan media pembelajaran yaitu software SPSS. Peserta didik mendapatkan informasi tentang pengertian SPSS, awal kemunculan SPSS dan kegunaan SPSS, langkah-langkah mengoperasikan software SPSS, hal ini menjadi menarik bagi peserta didik dalam menyimak informasi mengenai SPSS.

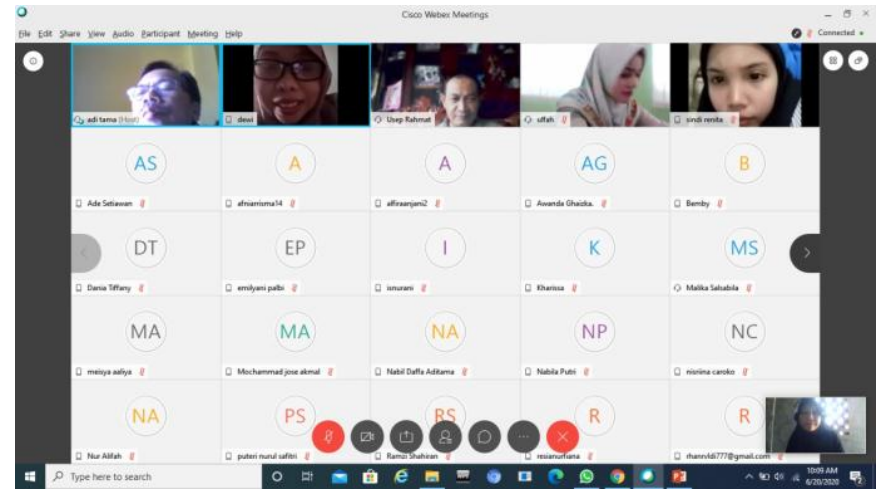

Gambar 1 Kegiatan materi software SPSS

Selanjutnya peserta didik melakukan workshop untuk mempraktekan penggunaan software SPSS dalam membuat tabel distribusi frekuensi, menghitung rata-rata, median, maupun modus. Salah satu peserta didik mencoba langsung dengan arahan pembimbing dari tim PKM.

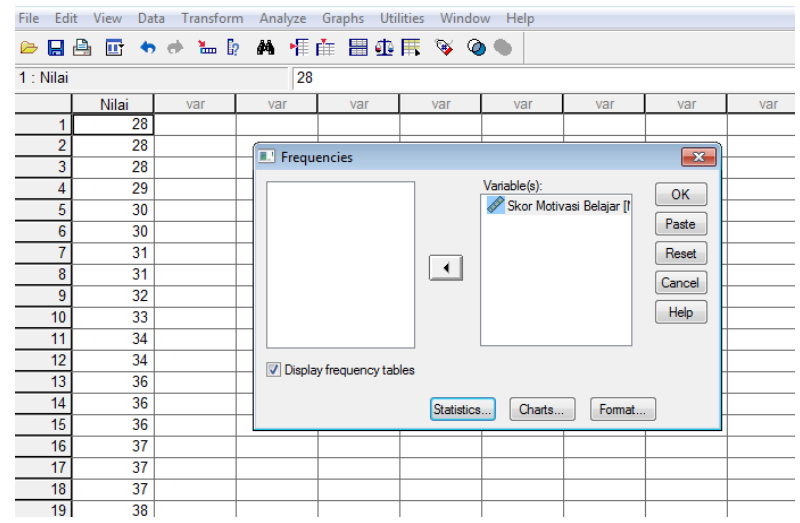

Gambar 2 Tampilan mengolah data statitik 


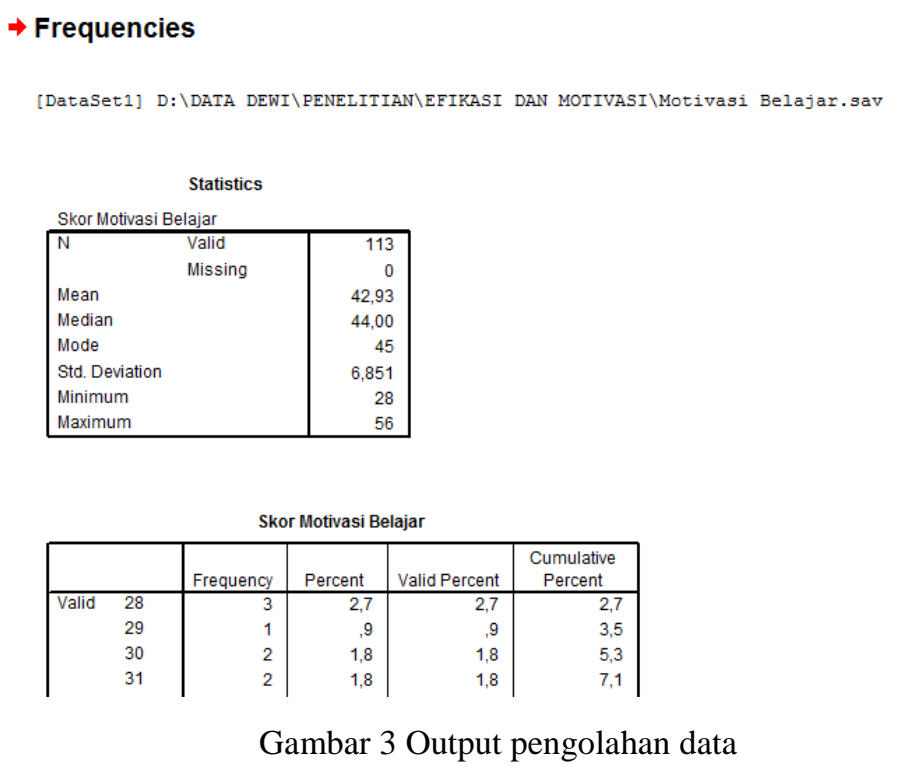

Penggunaan media pembelajaran berbasis ICT memang perlu terus dikenalkan kepada siswa SMA khusunya dalam meningkatkan pengetahuan dan keterampilan siswa. Apalagi saat ini di era digital tentunya siswa perlu banyak pengatahuan tambahan mengenai pengguaan komputer dan media pembelajaran salah satunya software SPSS dalam membantu mengolah data statistik khusnya statistik deskriptif yang siswa SMA pelajari.

Penggunaan software SPSS menjadi pengetahuan tambahan bagi siswa sebagai bahan pengetahuan dasar untuk dipelajari ditingkat lanjutan Universitas, karena software SPSS sudah banyak dilakukan dalam mengolah data hasil penelitian. Tidak menutup kemungkinan ini menjadi bahan penyemangat bagi siswa SMA khusunya SMAN 6 Tangerang Selatan untuk memulia belajar dalam menganilis atau membuat sebuah penelitian awal. Karena sesungguhnya kegiatan penelitian membantu siswa dalam mengembangkan dirinya, dalam memecahkan masalah dan mencari solusi dari permasalahan.

\section{SIMPULAN}

Berdasarkan hasil pengamatan selama proses pengabdian kepada masyarakat dan dilanjutkan dengan wawancara terhadap 3 siswa mengani proses pelatihan software SPSS dalam statistik desriptif pada materi statistika, memberikan hasil sebagai berikut: (1) Siswa sangat antusias mengikuti proses pelatihan menggunakan media pembelajaran software SPSS, karena mereka mendapat pengetahuan baru terkait penggunaan software SPSS dalam belajar matematika. (2) Meningkatkan pengatahuan dan pemahaman siswa SMAN 6 Tangerang Selatan untuk membantu dalam menyelesaikan permasalahan terkait pelajaran statistika. (3) Meningkatkan keterampilan siswa SMAN 6 Tangerang Selatan dalam penggunaan media pembelajaran berbasis ICT menggunakan software SPSS.

Mengingat cukup besar manfaat kegiatan pengabdian kepada msyarakat, maka selanjutnya kami merekomendasikan: (1) Mengadakan pelatihan serupa dengan jenis 
media pembelajaran berbasis software SPSS ditempat yang berbeda, agar semakin banyak pengetahuan baru yang didapat oleh siswa SMA dan jangkauan siswa SMA lebih luas. (2) Memberikan pelatihan dengan media pembelajaran berbasis software yang berbeda, agar menambah pengatahuan baru bagi siswa SMA. (3) Adanya pengawasan lanjutan dengan melakukan monitoring setelah adanya pengabdian kepada masyarakat, sehingga siswa benar-benar dapat memiliki pengetahuan dan keterampilan dalam menggunakan media pembelajaran berbasis software.

Selain itu kami dari tim PKM UNPAM tentunya dalam melakukan pengabdian kepada masyarakat berusaha melakukan semaksimal mungkin untuk mendapatkan hasil yang baik, namun karena keterbatasan media saat pandemi sehingga kami membutuhkan saran untuk perbaikan dalam melakukan pengabdian kepada masyarakat. Ke depan kami bisa melakukan dengan lebih baik dan bermanfaat lebih banyak bagi masyarakat.

\section{DAFTAR PUSTAKA}

Resti, H. N. S. dan I. (2018). Media Pembelajaran Interaktif Berbantu Software Lectora Inspire. Desimal Jurnal Matematika, 1. https://doi.org/10.24042/djm.v1i2.2583

Singh, K., Granville, M., \& Dika, S. (2002). Mathematics and science achievement: Effects of motivation, interest, and academic engagement. Journal of Educational Research, 95(6), 323-332. https://doi.org/10.1080/00220670209596607

Tambunan, H. (2018). The Dominant Factor of Teacher's Role as A Motivator of Students' Interest and Motivation in Mathematics Achievement. International Education Studies, 11(4), 144. https://doi.org/10.5539/ies.v11n4p144

Van der Kleij, F. M., Feskens, R. C. W., \& Eggen, T. J. H. M. (2015). Effects of Feedback in a Computer-Based Learning Environment on Students' Learning Outcomes: A Meta-Analysis. Review of Educational Research, 85(4), 475-511. https://doi.org/10.3102/0034654314564881

Zubair, S. (2015). Pengembangan Media Pembelajaran Berbasis Software Macromedia Flash 8 dan Power Point Materi Pokok Asam Basa. Jurnal Pendidikan Fisika, 3. http://journal.uin-alaudin.ac.id/indeks.php.PendidikanFisika 